\title{
The Model of College English Teachers' Transitional Development in Local Undergraduate Colleges for New Liberal Arts
}

\author{
Haiyan Wang ${ }^{1}$ \\ ${ }^{1}$ School of Foreign Languages, Northeast Petroleum University, Daqing, Heilongjiang 163318, China \\ *Corresponding author.Email: wanghaiyan@nepu.edu.cn
}

\begin{abstract}
Based on the study of the teachers' development and the problems of College English teachers from English for general purpose to English for academic purpose in local undergraduate colleges under the background of new liberal arts education, this paper introduced the EAP teacher certification standard in the United Kingdom, and put forward the four-dimensional model of teachers' development which involved the country and universities, communities, teachers and courses and provided the developing paths of certification systems, EAP learning and teaching communities, academic practice and EAP courses for teachers in the hope of improving teachers' competencies relating to academic practice, EAP students, curriculum development and programme implementation to meet the requirement of new liberal arts education.
\end{abstract}

Keywords: college English teachers, transitional development, EAP, new liberal arts

\section{INTRODUCTION}

Strengthening the construction of liberal arts was mentioned in the Notice of "Double Ten Thousands Plan" issued by the Ministry of Education of the People's Republic of China in April 2019. [1]This issue caused a heated discussion in the education sector. Traditionally, "liberal arts" refers to the subjects of humanities and social sciences. As one of the subjects of liberal arts, College English courses mainly focus on improving students' humanistic quality, and are mainly composed of famous British and American literature and cultural prose.

Under the background of the construction of new liberal arts, traditional liberal arts should be optimized and upgraded to realize the integration and development of disciplines. College English, as a compulsory course for college students in China, is carrying out the teaching reform to EAP (Academic English) and ESP (special purpose English). However, the key to teaching reform is the cooperation of teachers which means a certain relationship between teachers' transition and education transition. Only the transition of teachers can bring about the transition of education and teaching. Therefore, it is necessary to investigate and discuss the current situation of teachers' transitional development.

\section{OVERIVIEW OF TEACHERS' DEVELOPMENT}

William H. Bergquist \& Steven R. Phillips (1975) conducted a research on university teachers' development at the three levels of attitude, process and structure. [2] Since the 1960s, many universities in the United States have established audio-visual centres to service for college English curriculum consulting. The development of university teachers in Britain has experienced three stages. The first stage is the brewing period from the early 19th century to the 1950s. In this stage, the development activities of university teachers are lack of organization, and the personal development of university teachers is ignored. The second stage is from the 1960s to the 1970s .Under the background of popular education, the UK urgently needs to improve the "quality" of teachers. In order to promote the development of university teachers, university faculty development centres are constantly emerging, and teachers began to exchange learning by network. The third stage is the mature period from the 1980s to the present: the university teacher development centres in the UK have gradually matured, and focused on personal development, special program, and team development. [3] In Australia, university teachers' development has experienced the slow period 
from 1960s to 1970s which focused on teaching task and the rapid period since 1980 s which paid attention to the technology transition between universities and enterprises. Moreover, the Australian government encouraged university teachers to cooperate with enterprises and conduct scientific research. In the 1990s, higher education reform was carried out in Australia to evaluate the quality of higher education from teaching, scientific research and comprehensive work. In order to ensure the quality of higher education, most schools have carried out a variety of projects on university teachers' development to improve the quality of education. [4]

In 2003, Gong Bo, a domestic scholar, first studied the development of university teachers in his book on the symbiotic mechanism between university organizational culture and university teacher development. [5] Since the Fourth International Symposium on Higher-education Quality was held in 2006, the research on university teachers' development has gradually increased. In 2010, Linjie gave a more detailed description of the development of teachers. [6] Professor Pan Yuyuan (2007) put forward that the connotation of university teachers' development should also include professional, teaching and personal aspects. At present, the relevant researches on the connotation of university teachers' development can be divided into the following two categories: one is the process of regarding university teachers' development as a special occupation and obtaining the corresponding professional status. They emphasize the process of teachers' development, focusing on the historical development, social status, professional organizations, professional codes, etc. The other is about the individual development of university teachers, focusing on the improvement of teachers' economic level and social status and paying more attention to the internal improvement of teachers and their professional characteristics.

Domestic researches mainly focus on exploring the suitable models for teachers' development, how to support teachers' development externally, while foreign researches focus on organizing and carrying out various projects suitable for teachers' development. In terms of teachers' transitional development, the researches on the development of English teachers mainly focus on the transition of teachers' cognition, teaching from EGP to ESP, TCFL teachers, the possible ways of teachers' transitional development, the transition path, how to obtain support, and the evaluation of effects. In short, the academic community has reached a consensus on the transition of College English teachers, and agrees that there is an inevitable connection between education transition and teachers' development.

\section{PROBLEM S OF COLLEGE ENLISH TEACHERS' TRANSFORMATIONAL DEVELOPMENT}

The survey of the Foreign Teachers' Committee found that the College English curriculum system in China has been diversified, specialized and school-based. College English teaching has been in the transitional period, gradually changing from EGP to ESP, including EAP and EOP (Wang Shouren, Wang Haixiao, 2011; Cai Jigang, 2010).[7] The transition of College English education and the construction of new liberal arts are bound to require the transition of College English teachers. However, the responsibilities and challenges given by language teachers, especially for those from EGP make the transitional development imperative. The author, a teacher of EGP in Northeast Petroleum University, has been in EAP teaching and research since 2016. In the process of education reform, teachers have to face to face with many confusions and problems based on transitional development.

\subsection{General Confusions of EAP Teachers in Local Undergraduate Colleges}

English teachers in the transitional stage of academic English have many general confusions. First of all, what is academic English? Some teachers think teaching EGP with English vocabulary of disciplines. Some teachers consider EAP should be taught with different purposes compared to EGP. Secondly, is EAP should be taught on the base of ESP? Thirdly, how to help language teachers develop to fulfil the new teaching task concerning science and engineering?

\subsection{Insufficiency of Interdisciplinary Knowledge}

The liberal arts background of most College English teachers made them lack of interdisciplinary knowledge. On one hand, teachers did not know about the specific contents of different disciplines, on the other hand, they were not able to conduct interdisciplinary research. Moreover, the EAP teaching contents should combine with students' majors (Cai Jigang, 2019). [8] Therefore, how to enlarge the input of science and engineering knowledge is extremely urgent. The new liberal arts emphasizes to cultivate students' international vision and practical ability. Without interdisciplinary research experience, teachers are difficult to understand the papers of science and engineering, and unable to help students discuss academic topics and write articles at international conferences.

\subsection{Challenges in Teaching Methods}

Compared with EGP, Academic English involves a wide range of subjects, and the texts are more difficult for 
students. If the teacher adopts traditional teaching methods, students may lose interest and learn ineffectively. Therefore, teachers have to explore suitable methods to meet with different teaching goals and contents. In addition, Academic English teaching should be based on needs analysis. Obviously, most of teachers are not prepared for such idea and methods.

\section{COMPETENCY FRAMEWORK FOR EAP TEACHERS}

In the early 1970 s, in order to promote academic English teaching, university teachers from all over the UK held a seminar to solve the learning problems of Britain international college students in Birmingham. After the seminar, SELMOUS (Special English Language Materials for Overseas University Students) was established and a post-conference English for Academic Purposes was published. In 1989, the organization changed its name as BALEAP (British Association of Lecturers in English for Academic Purposes), which encouraged the rapid development of academic English teaching. [9] From April 2005 to January 2006, BALEAP conducted a three-year training for EAP practitioners and made a new framework to replace the standards implemented since 1989. The new framework set new regulations and standards for the development of EAP teachers. The four core competences of EAP teachers are competencies relating to academic practice, competencies relating to EAP students, competencies relating to curriculum development and competencies relating to programme implementation. Competencies relating to academic practice include academic contexts, disciplinary differences, academic discourse and personal learning, development and autonomy. Competencies relating to EAP students include student needs, student critical thinking and student autonomy. Competencies relating to curriculum development include syllabus and programme development, and text processing and text production. Competencies relating to programme implementation include teaching and assessment practices. They are listed in Table 1. [10]

Table 1 Competency framework for EAP teachers

\begin{tabular}{|l|l|l|l|}
\hline Academic practice & EAP students & Curriculum development & $\begin{array}{l}\text { Programme } \\
\text { implementation }\end{array}$ \\
\hline Academic contexts & Student needs & $\begin{array}{l}\text { Syllabus and programme } \\
\text { development }\end{array}$ & Teaching practices \\
\hline Disciplinary differences & Student critical thinking & $\begin{array}{l}\text { Text processing and text } \\
\text { production }\end{array}$ & Assessment practices \\
\cline { 1 - 2 } Academic discourse & Student autonomy \\
\cline { 1 - 2 } $\begin{array}{l}\text { Personal learning, } \\
\text { autonomy }\end{array}$ & & & \\
\hline
\end{tabular}

\section{THE MODEL OF EAP TEACHERS' TRANSITIONAL DEVELOPMENT}

According to the framework, the author took the academic research in NEPU into consideration to design a model of EAP teachers' competencies in hope of helping college English teachers find the direction and possible path of development for new liberal arts education. Considered the practical need of the teachers from EGP to EAP, the four-dimensional model of teachers' transitional development is shown as the Figure 1.

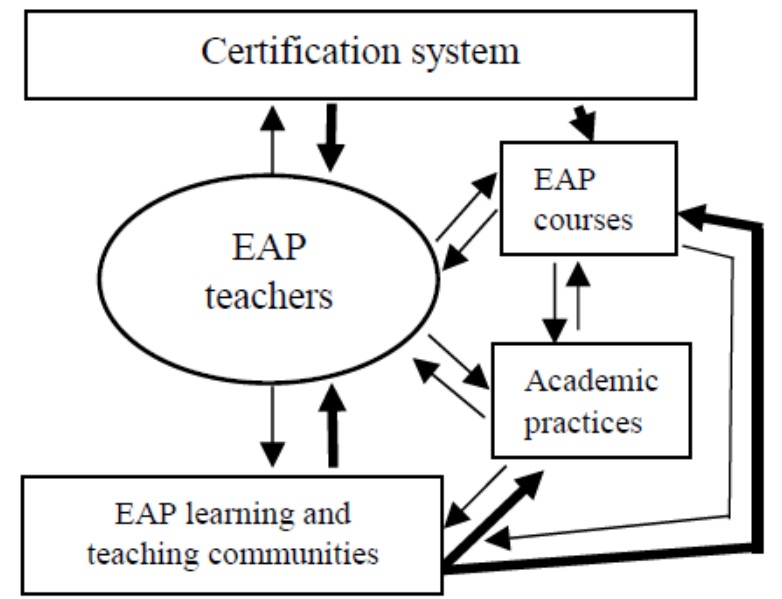

Figure 1 The four-dimensional model of EAP teachers' development

\subsection{The Certification System of EAP}

China English for Academic Purpose Association was founded in 2015. The CEAPA is considered as the authority to guide the development of academic English 
in China. The further advice for it is to set up a system of certification. The system should contain not only the certification of EAP teachers but also the level test of students in China. In addition to the certification of CEAPA, colleges and universities, especially local undergraduate colleges and universities with different problems, should set up specific local policies under the CEAPA to encourage and promote the teachers' transitional development. With the certification of CEAPA and local colleges and universities, EAP teachers can have a clear idea of EAP teaching and individual development. The system is necessary for both the EAP teachers and courses.

\subsection{EAP Learning and Teaching Communities}

According to the standard of CEAPA and local colleges and universities, EAP learning and teaching communities in each school should be established to dedicate to assisting teachers' transitional development. In order to improve teachers' competencies relating to academic practice, EAP students, curriculum development and programme implementation, domestic and international training, such as seminars, workshops, online courses, should be a routine. Moreover, learning and teaching teams should be encouraged in the communities. Teachers, post-graduates from different disciplines, even from other university can sign up for the exchange learning. Both teachers and communities can be beneficial.

\subsection{Academic Practice}

With the assistant of EAP learning and teaching communities, teachers can be engaged in academic practices by themselves or by teams. Teachers can reap the benefit of individual development and teaching researches. The academic practices of EAP teachers also a reward for EAP courses. The academic experiences are necessary for EAP teachers to make further study on the current researches and know the need of modern researches to keep pace with the world and update teaching materials and methods. On the contrary, the teaching of EAP courses also promote their researches.

\subsection{EAP Courses}

EAP courses, as an important factor, connected teachers with students. In terms of qualification of education, the construction and assessment of courses play a critical role. To a certain degree, courses can be a symbol of teachers' competencies. In the model of fourdimensional model of EAP teachers' development, the interactive effects of EAP courses and teachers is obvious. The EAP teachers' transitional development push the construction of courses forward, and the courses impel teachers' self-learning. Another interactive action is between EAP courses and academic practices. EAP courses are part of academic practices which certainly can be the contents of courses. Moreover, the support of EAP learning and teaching communities play an important role in EAP courses, and the courses enlarge the region of the communities.

\section{CONCLUSION}

Teaching from EGP to EAP is the need of the construction of new liberal arts, and the transitional development of EAP is critical to the reform. Based on the study of teachers' development and the analysis of problems of teachers' transitional development, the author designed the four-dimensional model directed by the competency framework for EAP teachers of UK. The model includes four levels: system, communities, teachers and courses. The system refers to the country and universities which guide the teachers' development generally; communities means EAP learning and teaching communities which assist teachers to improve themselves; teachers are the men of action, and EAP courses are the carrier of teachers' development. Focusing on the EAP teachers' development, four dimensions are used to be as the ways of such transition, that is, certification system, EAP learning and teaching communities, academic practice and EAP courses. Different dimensions influence and promote each other to contribute to the College English teachers' competencies for new liberal arts education.

\section{ACKNOWLEDGMENT}

This work was supported by Northeast Petroleum University Innovation Fund for Art, Physical Education \& Foreign language majors (2020YTW-W-01).

\section{REFERENCES}

[1] The Ministry of Education of the People's Republic of China (2019) The Notice of "Double Ten Thousands

Plan"http://www.moe.gov.cn/srcsite/A08/s7056/20 1904/t20190409_377216.html.

[2] Bergquist, W.H.\&S.R. Phillips (1975) Components of an Effective Faculty Development Program, The Journal of Higher Education, 46:177-211.

[3] Hu Gang (2012) The Formation, Features and Enlightenments of University Teacher Development System in UK, 33:157-160.

[4] Allan Luke and Felicity McArdle (2009) A Model for Research-Based State Professional Development Policy in Australia Asia-Pacific Journal of Teacher Education, 20:231-251

[5] Gong Bo (2003) On the Symbiotic Mechanism of University Organizational Culture and teachers' 
Development, Forum on Contemporary Education, 000:67-68.

[6] Lin Jie (2010) The Faculty Development Agencies in U. S. Colleges and Universities, Tsinghua Journal of Education, 31:49-56.

[7] Cai Jigang, Liao Zhaoyong (2010) Academic English or Professional English-On the reorientation of ESP Teaching in Chinese Universities, Foreign Language Education, 31:47-50

[8] Cai Jigang (2019) Further Research on Academic English: EAP or EGP?, Journal of Xi'an International Studies University, 27:7-11

[9] Jordan R.R. (2002) The Growth of EAP in Britain Journal of English for Academic Purposes, 1:69-78.

[10] BALEAP (2012) EAP Teacher Competency Framework http://www.teap@baleap.org.uk 